
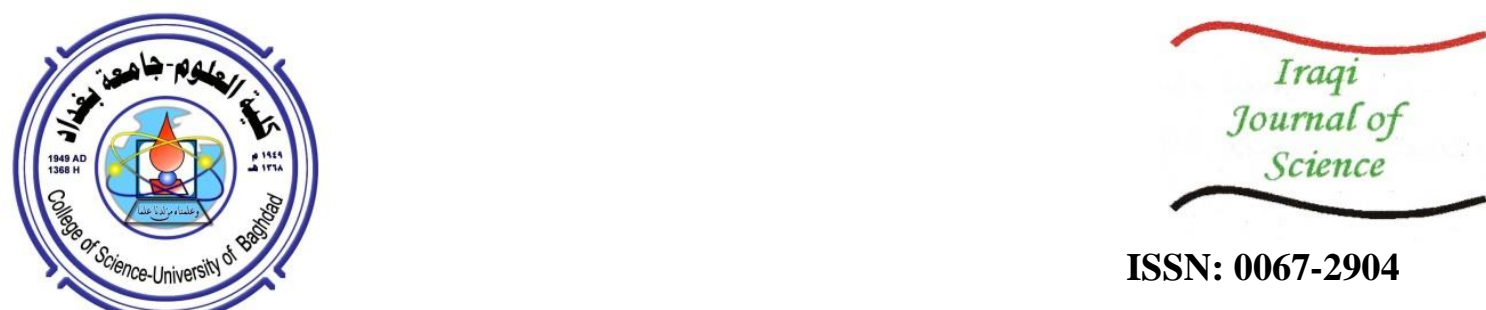

ISSN: 0067-2904

\title{
The Sedimentology of the Late Campanian-Maastrichtian Sequence, Southwestern Iraq
}

\author{
Mazin Y. Tamar-Agha*1, Muzahim A. Basi ${ }^{2}$ \\ ${ }^{1}$ Department of Geology, College of Science, University of Baghdad, Jadiriya, Baghdad \\ ${ }^{2}$ Department of Petroleum Engineering, Al-Farabi University College, Baghdad
}

Received: $18 / 4 / 2020$

Accepted: 22/7/2020

\begin{abstract}
Petrography, diagenesis, and facies analyses as well as the depositional environments of the late Campanian-Maastrichtian sequence in southwestern Iraq are studied in five keyholes. The sequence incorporates parts of the Hartha, Shiranish and Tayarat Formations. The Hartha Formation comprises creamy and organodetrital dolomite, grey dolomitic marl, and evaporites. The Shiranish Formation is composed of grey marl and claystone, whereas the Tayarat Formation is composed of grey ash, along with tough and fossiliferous dolomitic limestone inter-bedded with grey mudstone layers and/or wisps. Several diagenetic processes affected the sequence, such as neomorphic replacement, dissolution, dolomitization, and sulphate development. Some of these processes obliterated the primary textures. The late Campanian-Maastrichtian sequence consists of three microfacies (Dolomitic Intraclastic Limestone, Dolomitized Biomicrite, and Biomicrosparite Microfacies) and two lithofacies (Mudrock and Sulphates-Rock Lithofacies), in addition to Fine- to Medium-Crystalline Dolomite Lithotype.

The Hartha Formation is evaporitic, possibly with supratidal sabkha deposits. The overlying Tayarat and Shiranish Formations reflect deposition in a warm tropical to subtropical reefal and open marine conditions, as deduced from faunal assemblages. Some effects of deep marine condition are evident by the presence of Shiranish facies. The sequence represents deposition in the central reef- fore reef area. The absence of isolated back-reef lagoon facies suggests that the reef was patchy without isolation of water in the middle shelf region. However, at the top of the sequence, i.e. at the end of the Cretaceous Period, restricted lagoons seem to have dominated the studied succession.
\end{abstract}

Keywords: Campanian, Maastrichtian, Hartha, Shiranish, Tayarat Formations, Depositional environment, Diagenesis.

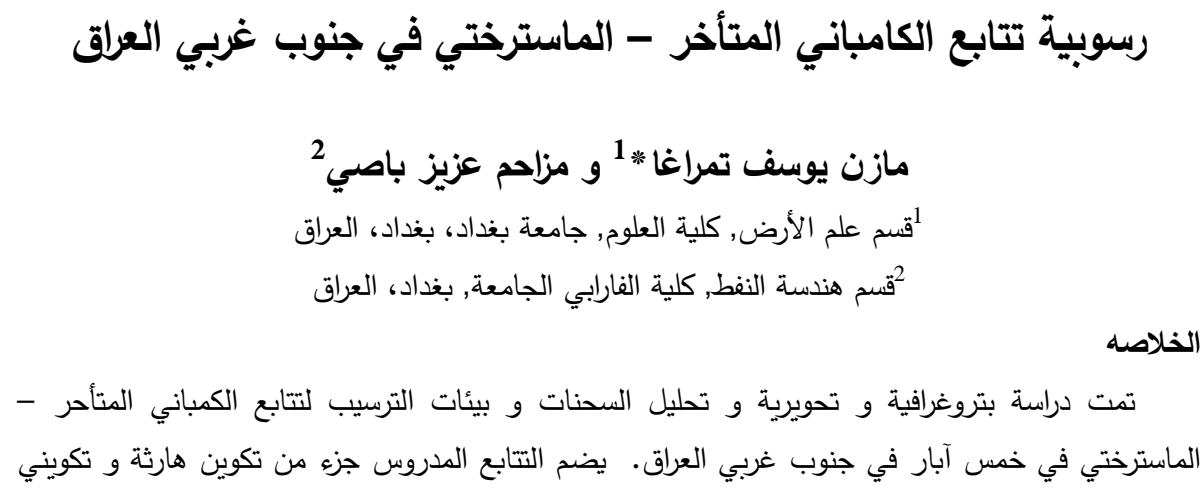

*Email: mtamaragha@yahoo.com 


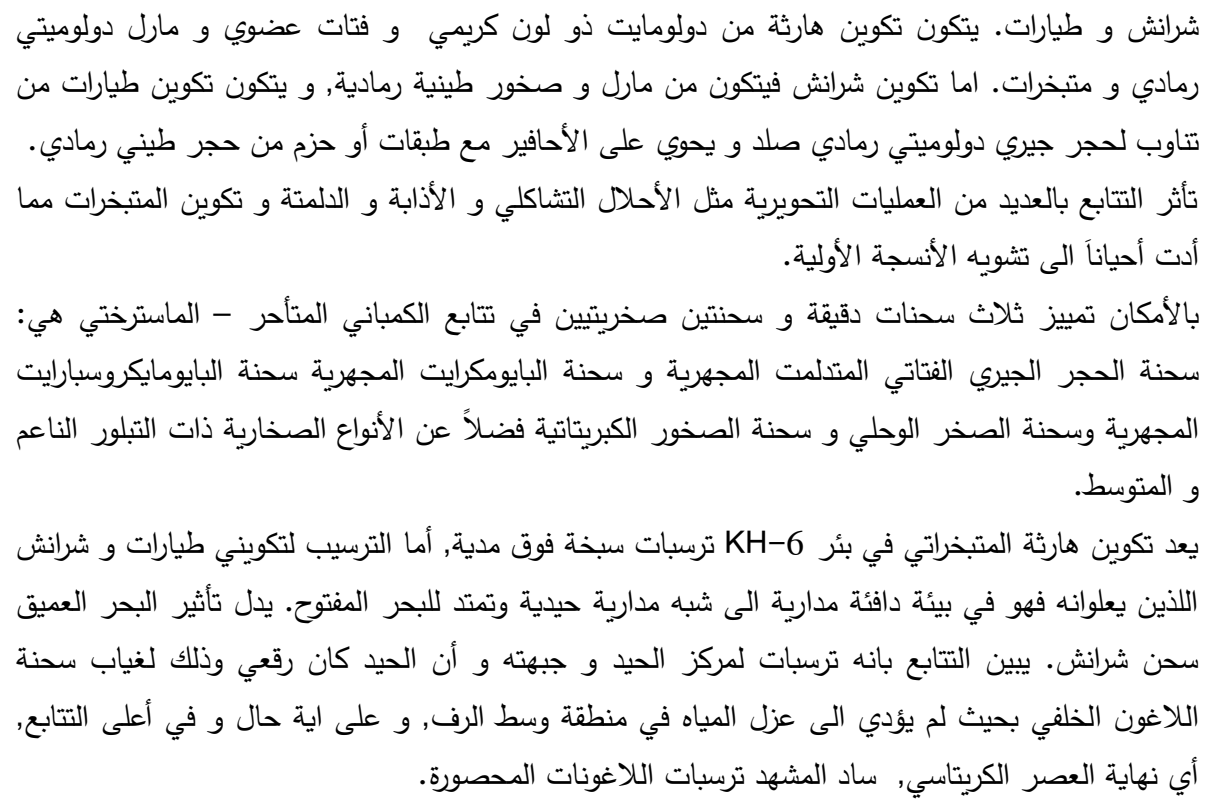

\section{Introduction}

A comprehensive project was executed during the late seventies and early eighties of the last Century by the Iraq Geological Survey directorate concerning the hydrogeology of the Southern Desert of Iraq. Eleven keyholes and two subsidiary boreholes (Fig. 1) were drilled to various depths (full-core drilling) ranging from 120 to $600 \mathrm{~m}$. Both keyholes and boreholes penetrated three successions, namely late Campanian-Maastrichtian, Paleogene, and Neogene successions. A preliminary study was carried out on the collected samples in terms of Petrology (Basi, 1984) [1,] while Palaeontology and Geochemistry were studied by others and presented as internal reports. Finally the work was compiled, discussed, and interpreted in a final report $[2,3]$.

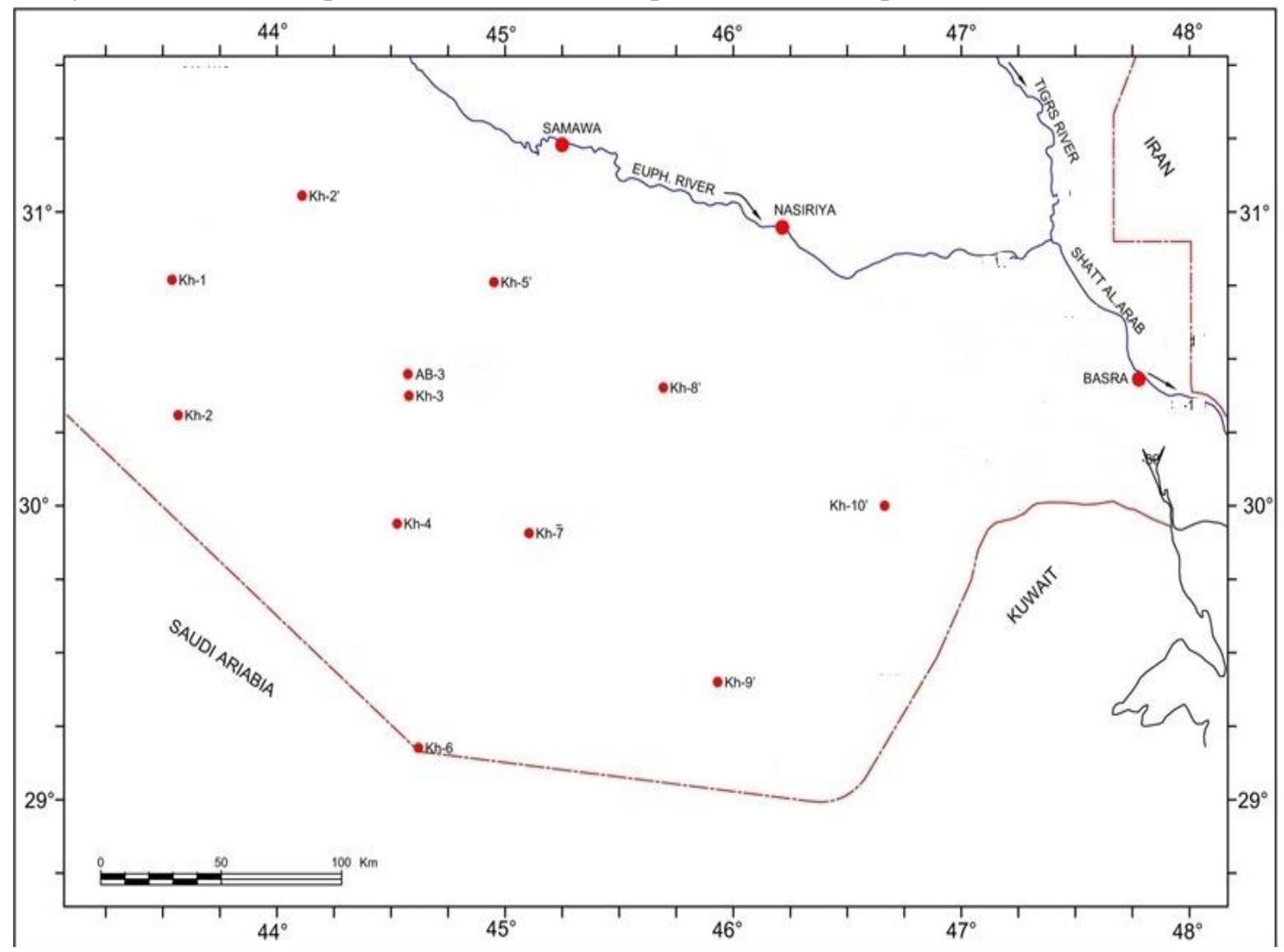

Figure 1- Location map of the studied area 
A summary of the knowledge about Iraq's stratigraphic studies on the region was then compiled [4, 5] and a series of isopach maps for a set of formations ranging from the Yamama to the Fatha (previously named Lower Fars) were constructed [6]. Subsequent to this work, the amount of works on the area was increased by the Iraq Geological Survey Teams [1, 2, 3, 7, 8, 9], which resulted mainly in producing maps (scale 1:100 000) accompanied with unpublished reports. In general, few researches on the late Campanian-Maastrichtian sequence were conducted [e.g. 10, 11, 12].

The aim of this study is to investigate the facies and deduce the depositional environments of the late Campanian-Maastrichtian sequence. In addition, we aimed to study the diagenesis, especially the rocks of the studied sequence, in general, which have suffered a high degree of diagenetical modification.

\section{Geological Setting}

The study area represents part of the Southern Desert Subzone of the Arabian Inner Platform of the northern part of the Arabian Plate [13]. It has suffered a remarkably slight deformation. The structural elements are almost limited to very gently-lying sedimentary strata, mostly of carbonates, mudrock, and evaporite successions. The strata incline with very gentle gradient towards the Mesopotamian Alluvial Plain. Some of the folds can be attributed to tectonic activities whereas others are expected to be secondary structures. They are solution collapse structures which might have been initiated by tectonic features, such as faults. The strata were then bent by flexuring and subsequent differential settlement and readjustment [14].

The studied succession is equivalent to the upper part of Tectonostratigraphic Megasequence AP 9 (TMS AP9) [15]. The studied sequence incorporates the upper part of the Hartha Formation (upper Campanian-Maastrichtian), the Shiranish Formation, and the Tayarat Formation (Maastrichtian). Darmoian [16] introduced the name Qurna Formation instead of Shiranish Formation, since it is a lens of Shiranish facies in the Tayarat Formation. Correlation diagrams are given in Figure-2.

The Hartha Formation is reached in KH-6 in the Ansab area only. The formation was first described by Rabanit in 1952 [4] and, later, Owen and Nasr [17] selected an interval in the B.P.C well $\mathrm{Zu}-3$ as its type section. In the type section, the Hartha Formation is about $128 \mathrm{~m}$ of organodetrital glauconitic limestone with grey marls and green shale. The limestone is strongly dolomitized in places. Hartha Formation conformably overlies Sa'adi Formation in the type, locality, and disconformably that underlies the Shiranish (Qurna Formation). The Hartha Formation changes westwards into dolomite and anhydrite. The evaporite nodules and beds are noticed at the top of the sequence in KH-6. The thickness of the penetrated part is about 16.4 metres. It is distinguished by alternation of evaporitic layers with creamy organodetrital dolomite grey dolomitic marl. Claystones are present at many intervals (drilling depths 580.0, 582.0, and 589.0 metres). Bioturbations and algal laminations are noticed in the dolomite. Tiny gastropods are not uncommon.

The Tayarat Formation was introduced by Henson in1940 in an unpublished report for about 30 metres of rubbly, porous, white, buff and pink, rather chalky, fossiliferous, recrystallized, locally sandy limestone, about $37 \mathrm{~km}$ south of Rutbah town [4]. The Qurna Formation was introduced by Rabanit in 1952 in an unpublished report [4] and later, Owen and Nasr [17] selected an interval in the B.P.C well $\mathrm{Zu}-3$ as its type section. In the type section, the Qurna Formation is about 112 metres of buff or ash grey globigerinal marl, sometimes dolomitic, and occasional marly limestone beds with rich microfauna. Similar globigerinal marls of the same age make up part of the much thicker Shiranish Formation. However, the name Shiranish was adopted here. The Tayarat and Shiranish Formations in the studied area are found in subsurface sections only. The former was reached in five keyholes, namely Kh-3, at Al-Salman depression, Kh-4 at Takhadid, Kh-5 at Salhobiya village, Kh-7 at Abu Radham, and Kh-6 at Ansab. In the Kh-5 at Salhobiya, the penetration took place using rockbit (cuttings). Only at Kh-6 the whole sequence is penetrated. In KH-6, the Tayarat deposits comprise a lens of Qurna. In the other keyholes, only the uppermost few metres are penetrated. Considering the recent results and the previous works of the oil companies, it is concluded that the Tayarat Formation interfingers with the Shiranish Formation, especially in the western part of the study area. 


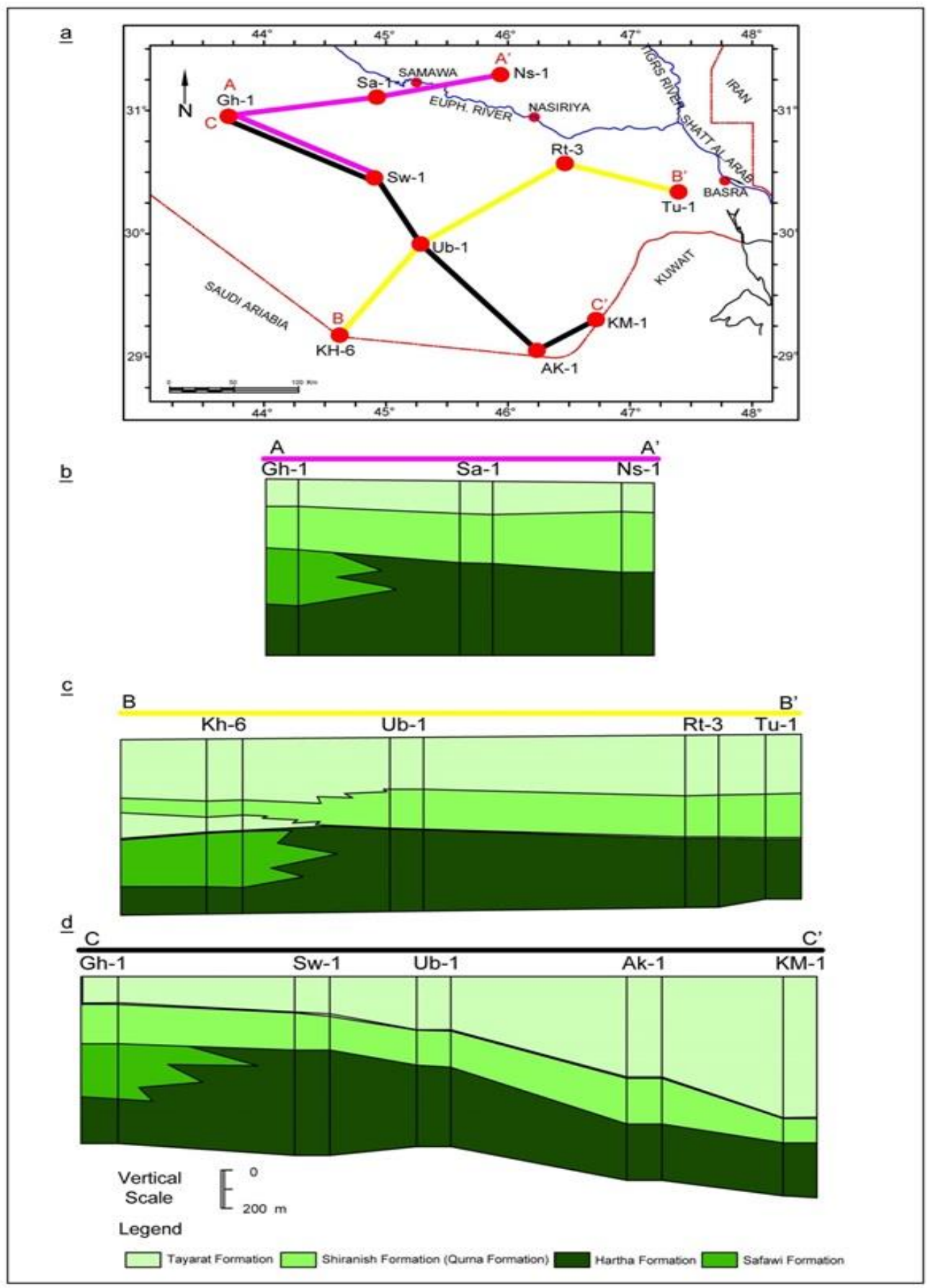

Figure 2- a) Map showing the cross section lines along which the late Campanian-Maastrichtian formations are correlated. b) Correlation along section line A-A'. c) Correlation along section line B-B' , and d) Correlation along section line C-C' (from Tamar-Agha and Al-Sagri, 2015) [12].

\section{Materials and Methods}

Five of the keyholes drilled for the hydrogeology of the Southern Desert of Iraq project have partly penetrated the late Campanian-Maastrichtian sequence, namely KH-3 at Al-Salman depression, KH-4 at Takhadid area, Kh-5 at Salhobiya, KH-6 at Ansab area, and KH-7 at Abu Radham area. The core representing the sequence was described by the authors and 132 core samples were taken from them. All samples were thin sectioned and stained with Alizarin red $\mathrm{S}$ for petrographic study. During this work, Folk's classification [18] is generally adopted, although, on few occasions, reference is made to Dunham's terminology [19]. 


\section{Petrography and Diagenetic History}

Several diagenetic processes took place in this succession since the sediments were laid down. In some areas, such as KH-6 at Ansab and KH-3 at Al-Salman depression, the sediments were partially dolomitized, which allowed the study of the preceding processes. In KH-4 at Takhadid area, however, pervasive dolomitization has almost eradicated all imprints left by those processes which preceded the dolomitization. The following diagenetic processes seem to have operated after deposition of the carbonate and/or during the accretion of the carbonate build-up. Deposition seems to have taken place in a carbonate platform with patchy distribution of carbonate build-up. The carbonate build-up seems not to have yielded a back-reef lagoon. The diagenetic processes in their expected order are:

1) Neomorphic replacement - The original sediments are believed to constitute both carbonate mud and allochems. The petrographic descriptions showed that the carbonate mud was transformed into micritic matrix. The allochems are represented chiefly by wide spectrum of faunal assemblage. The tests and shells of these skeletal fragments are made of aragonite, high- and low-magnesian calcite [20].

These sediments were transformed to limestone by inversion of aragonite mud and the aragonite in the skeletal components to calcite. Besides, it involves the recrystallization of the calcite mud and calcite fibres into calcite mosaic. Hence, both pseudomorphic and non-pseudomorphic replacements are encountered. This terminology explains the origin of common dolomite fabrics $[21,22]$. In the present work, the term pseudomorphic replacement is used to describe the inversion of aragonite and/or recrystallization of calcite as volume for volume replacement and maintaining the original skeletal architecture. Non-pseudomorphic replacement incorporates those processes whereby the original architecture is demolished by the growth of new fabrics. The original pattern is expected to have gone into solution followed by the precipitation of a calcite mosaic.

These processes are collectively grouped under the umbrella of cementation and can form by the fresh-water activity and, to a lesser extent, in the marine conditions. Also, the original textures of the skeletal particles, which are formed of aragonite, are commonly not preserved [23, 24]. Instead, a drusy mosaic of calcite is formed. Friedman [23] added that those skeletal particles which are formed of high- to low-magnesian remain without any significant change in their original texture.

2- Dissolution: Voids are not uncommonly found in ancient limestones. Some of these voids remain empty whereas others are filled with secondary material. The voids, in general, are produced by dissolution of aragonite, high- and low-magnesian calcite in natural water. The latter is the least soluble mineral than the rest $[23,26]$. Voids in the form of biomolds are abundant in the carbonates of the late Campanian-Maastrichtian sequence. Since the deposits in question are partly reefal, high primary porosity is expected. Secondary porosity was also developed during the course of diagenesis. The voids produced as a secondary porosity are mostly formed by simple dissolution of skeletal fragments. The dissolution seems selective as some fossils are now represented by biomolds or the moulds are filled by cement. A clear imparity is noticed in the dissolution of matrix and allochems. The matrix is hardly affected by dissolution. This may be attributed to the difference in the composition of the different constituents.

The matrix is most probably consisted of low-magnesian calcite during the process of dissolution. The skeletal fragments on the other hand seem to have constituted high- magnesian calcite, aragonite and, to a lesser extent, low-magnesian calcite $[20,25,26]$. The low-magnesian calcite is more resistant to dissolution. Two kinds of vugs are found, having the following setting:

a) Some samples showed the presence of skeletal fragments filled with drusy and blocky cement, formed of fibrous calcite and biomolds embedded in micritic matrix. Such textures can possibly be formed if the dissolution preceded the other processes, i.e. early diagenetical dissolution. By such process, the aragonitic shells and tests which are formed of low-magnesian calcite and aragonite are more susceptible to solution than the rest. Later neomorphic processes led to fossils having their internal architecture preserved. The moulds produced by the early stage diagenesis either remained empty or were filled later by drusy and blocky cement.

b) Other samples demonstrated the presence of dolomitized (finely crystalline) skeletal fragments and biomolds embedded in finely- and medium-crystalline dolomitized matrix. Such rocks can possibly be formed by one of the following manners:

- Selective dolomitization, whereby shells, tests, and matrix formed of low-magnesian calcite are the least affected, as they commonly refrain from metasomatic replacement by dolomite. 
- Dissolution preceding the dolomitization, i.e. late diagenetic dolomitization. Accordingly, the skeletal particles which previously refrained from dolomitization are more susceptible to dissolution and thus leaving an empty space (mould) instead. Another way to explain these features is the wholesale dolomitization of the limestone described in item (a) above.

Either of these procedures can be deduced. The authors are not totally committed to either of these procedures, rather they are relying on the intuition they tend to believe in the first explanation.

3) Dolomitization: This process is undoubtedly the most dominant and ubiquitous process amongst all other processes. The entire succession in KH-4 at Takhadid, for example, was affected by dolomitization. There are many attempts to summarize most models for dolomitization to fit into one of the following genetic classifications: penecontemporaneous dolomitization (the synsedimentary replacement of sediments), early-diagenetic dolomitization (replacement after consolidation controlled predominantly by surface generated fluids), and late-diagenetic dolomitization (replacement after consolidation or burial by reacting fluids generated in the subsurface) [24-29].

In the late Campanian-Maastrichtian sequence, the presence of dolomitized skeletal fragments is usually taken as a sufficient proof to disqualify the primary origin of dolomite (Figure- 3). The 'primary' origin is taken here to mean the direct precipitation of dolomite by sea water, unlike the sense inferred by Nicholas and Siberling [25]. The dolomite has a patchy distribution. In KH-3 and $\mathrm{KH}-6$, primary limestone and dolomitic limestone are encountered. In $\mathrm{KH}-4$, the entire sequence is dolomitized. This kind of distribution further emphasizes the secondary origin of these dolomites. The dolomitization front commonly cuts across the bedding planes of unaltered limestones. The dolomite crystals are fine to medium crystalline $(0.06$ to $0.25 \mathrm{~mm})$, zoned, and commonly showing equigranular rhombic texture, i.e. mosaic texture. Some rocks show anhedral, equigranular texture, i.e. xenotopic texture. Relics of the obliterated bioclasts can still be observed. Considering the evidence collected, this kind of dolomitization is late diagenetic (Figure- 3). The late diagenetic dolomitization can be produced during the migration of the intrastratal solution containing dissolved ions [26]. In general, the dolomites in the late Campanian-Maastrichtian sequence can be correlated with Mattes and Mountjoy's [27] dolomite types 2 and 4, i.e. mosaic and white sparry dolomite, respectively.
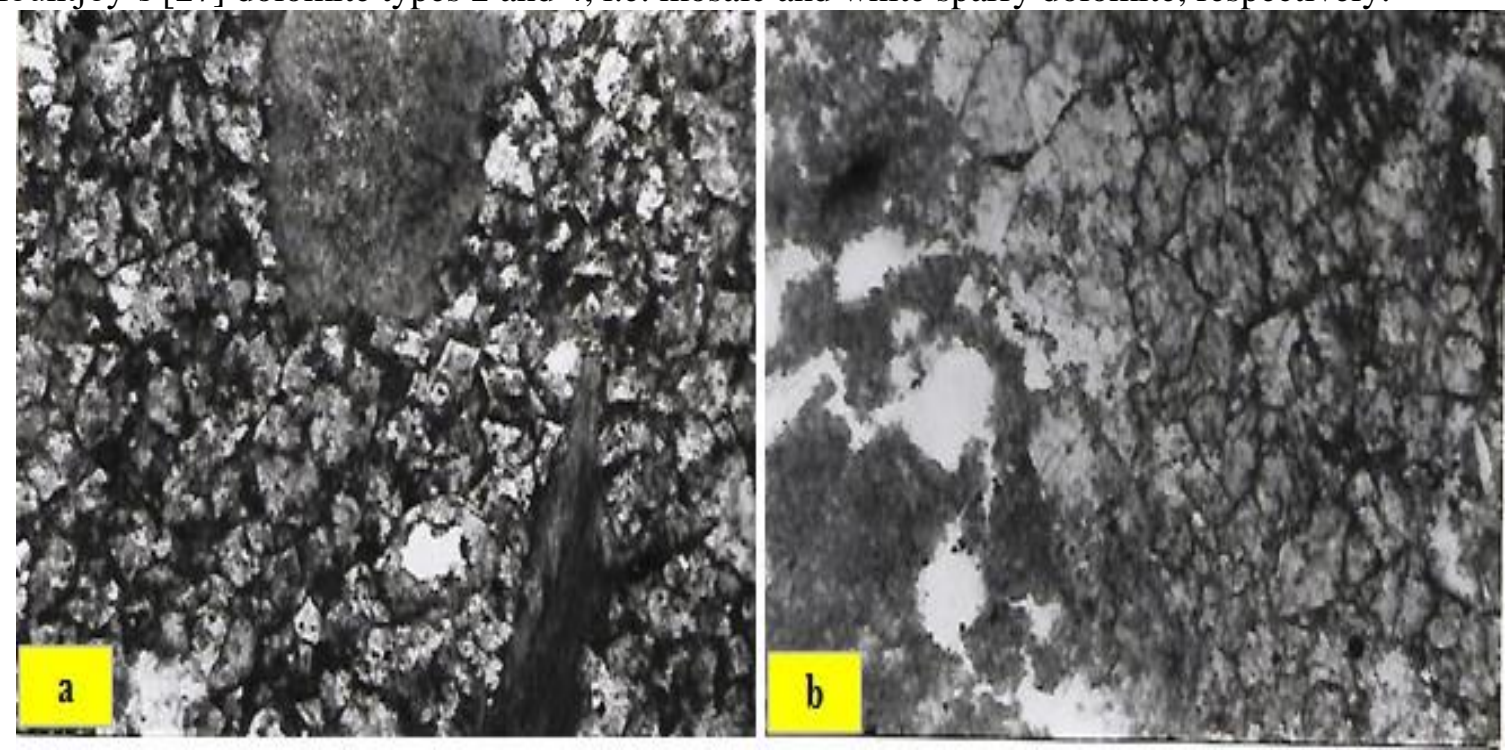

Figure 3- Photomicrographs showing selective dolomitization. The skeletal fragments usually remain unaltered. Both samples are from Tayarat Formation, KH-4 at Takhadid. Plane polarized light x35.

4) Sulphate development: The sulphates grow as interlocked crystals of gypsum and anhydrite in the pore space representing the intraparticle voids, such as the spaces in the fossils, or even replacing some of the pre-existing dolomite (Figure- 4). The gypsum is usually found in the periphery whereas anhydrite occupies the centre. The crystals are usually radial or bladed (Figure- 5). The gypsum and anhydrite are frequently found to contain carbonate inclusions as remains. Gypsum usually replaces anhydrite with the destruction of its original fabric. 

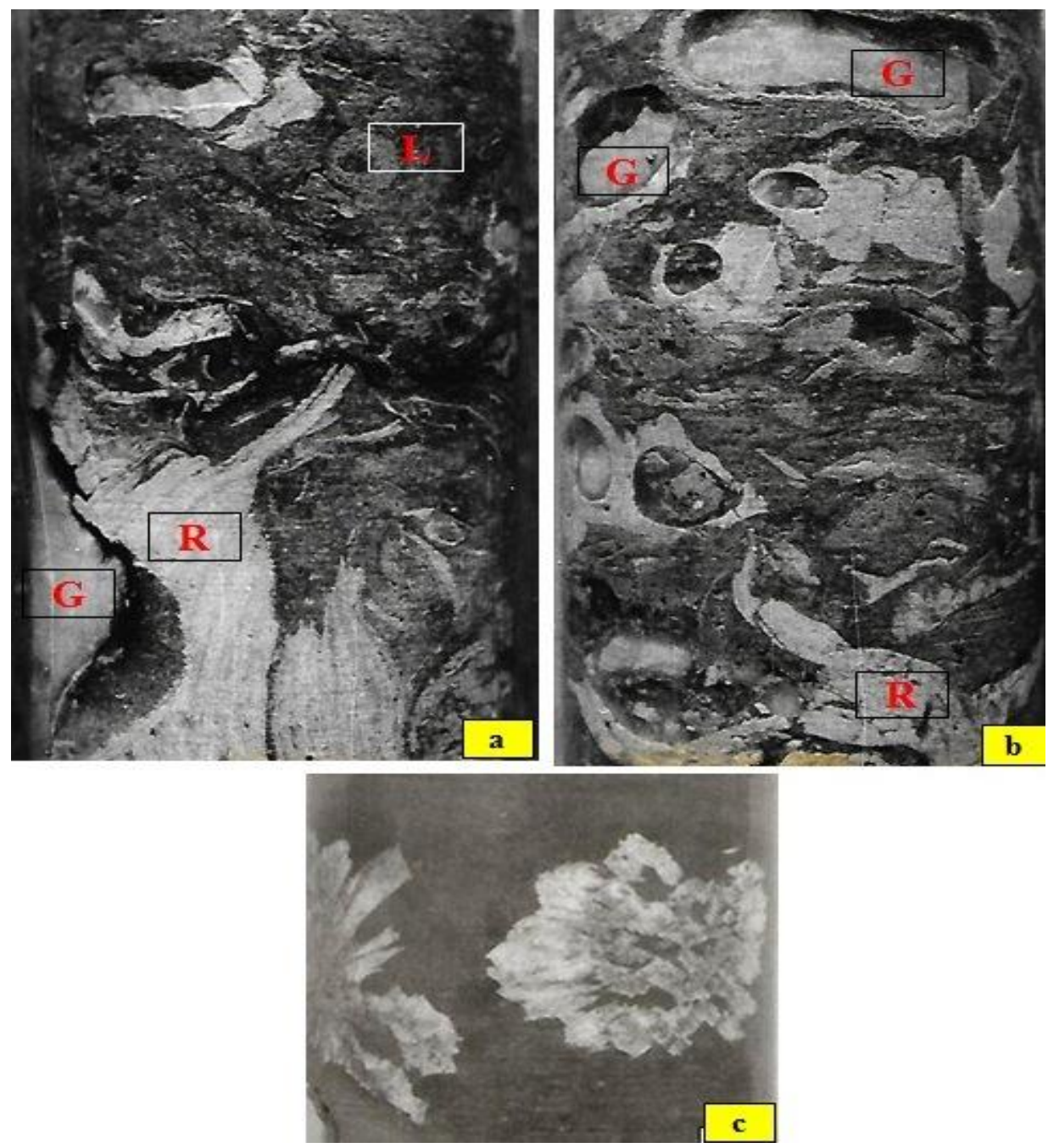

Figure 4-Sulphate nodules in the Tayarat Formation, diameter of the core is $11 \mathrm{~cm}$. a) and b) - A solitary nodule of gypsum and anhydrite $(\mathrm{G})$ grown in voids in organodetrital dolomitic limestone (calcirudite) with rudists (R) and Loftusia sp. (L) - a cross section, from KH-6 at Ansab (sample a - at drilling depth $383.4 \mathrm{~m}$ and sample $\mathrm{b}$ - at drilling depth $382.0 \mathrm{~m}$ ). c) Celestite rosettes in organic dolomitic limestone from KH-6 at Ansab, at drilling depth $385.1 \mathrm{~m}$.

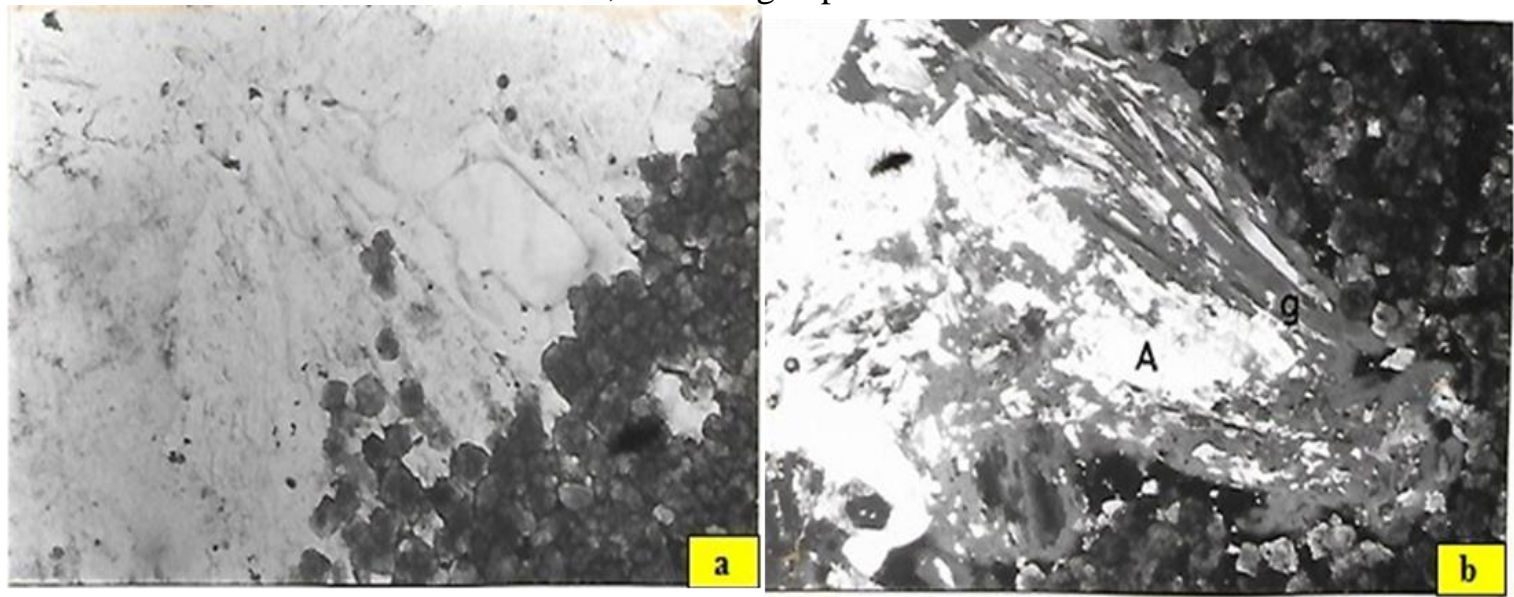

Figure 5-Photomicrographs of gypsum nodules in the Tayarat Formation from KH-4 at Takhadid: a) Fibrous and radial blades of gypsum and anhydrite crystals with finely crystalline dolomite rhombs. Some of the dolomite rhombs are inclusions in the evaporite, reflecting its replacive origin. Planepolarized light X45. b) Fibrous and radial blades of gypsum and anhydrite. The light area is anhydrite (A) which generally occupies the central part of the nodule, whereas the grey is gypsum (g) which is found at the periphery (Crossed Nicols X45). 


\section{Facies Analysis}

The term 'biogenic' is used here frequently, especially in the dolostone. It is meant to indicate the presence of fossils and avoid the strict terminology given by Folk to distinguish fossiliferous (1-10\%) and the biomicrite or biosparite (10\%) fossils. During the course of the thin section studies, the biota recognized is a number of invertebrate fossils such as pelecypods, gastropods. and bryozoans, as well as other microfossils such as nummulites, miliolids, ostracods, a1gae etc. The classification of the rock samples into microfacies was attempted but, on some occasions, it was not possible. The cause is obviously the intensive destruction imposed by the physicochemical alterations. Instead, the rock samples were grouped into "lithotype" which are considered as a function of diagenesis rather than depositional environment. The use of terminology $[18,19]$ and interpretations relied on several sources [20, 28, 29, 30, 31].

The late Campanian-Maastrichtian sequence is characterized by five facies and severely dolomitized intervals which cannot be assigned to the original facies and thus lump-summed under a class 6, called here lithotype. These facies and lithotypes are:

1) Dolomitic Intraclastic Limestone Microfacies: This facies is exceptional in the studied area and is restricted to the Tayarat Formation only. It can be classified as dolomitic Intrabiosparite and dolomitic Intrabiomicrite (Figure-6). It can also be referred to as Intraclastic Packstone-Grainstone Rudite Microfacies, using Dunham's terminology.

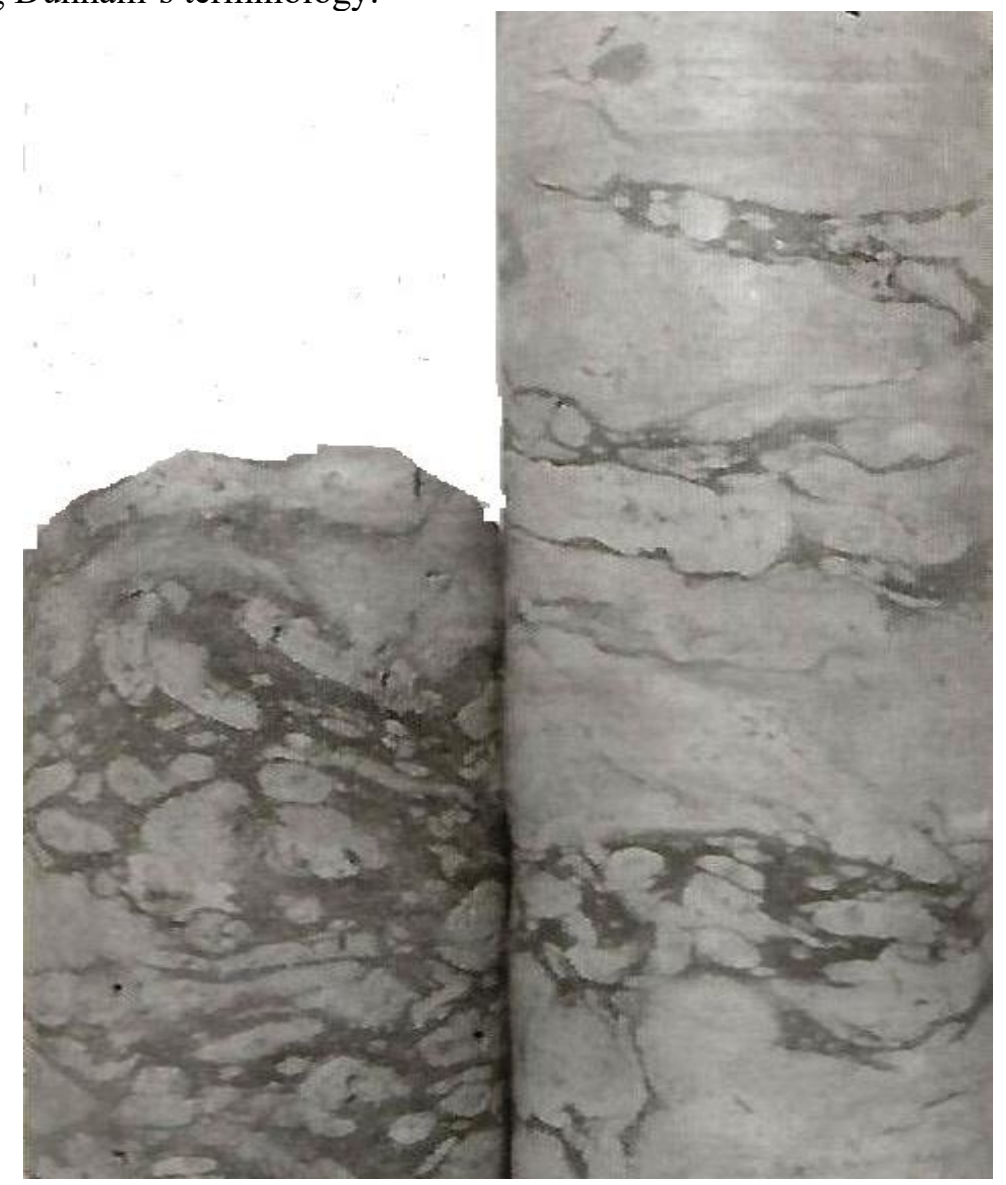

Figure 6-Dolomitic Intraclastic Limestone Lithofacies representing reef talus from the Tayarat Formation, KH-6 at Ansab (drilling depth is 355.7 metres and width of core is $11 \mathrm{~cm}$ ).

This lithofacies comprises endogenetic rock fragments of varying sizes, reaching up to 20 centimetres in diameter, embedded in a primary clay micritic matrix (Figures- 6). The intraclasts are generally cobble size with angular and sharp boundaries with enveloping matrix. The intraclasts are intrabasinal products and are essentially reworked fragments of penecontemporaneous lithified lime deposits (Figure-6).

The limestone fragments are formed of sparsely to densely fossiliferous biomicrosparite (wackestone). The fossils are normally diversified, being of various types of forams, dasycledacean 
algae, echinoids, fragments of corals, some rudist fragments, pelecypods, brachiopods, and ostracods (Figures- $4 \mathrm{a}$ and b). Some phosphatic grains are also present. Dolomite is present in the fragments in the form of disseminated rhombs. Pyrite can often be found in small patches or framboids. The claystone forms an enveloping matrix which is usually densely penetrated with rhombs of dolomites. Fossils are rare, represented by various forams and echinoids. Some phosphatic fragments and pyrites are also present. The claystone is characterized by pigmentation of organic substances. The intraclasts are seemingly intrabasinal products and are essentially reworked fragments of penecontemporaneous lithified lime deposits. The lithification of the clasts is inferred from their sharp boundaries.

It is believed that this facies represent reef talus. The clasts were formerly, more or less, a continuous bed, as evident from the various structures on the fragments (such as mottling, bioturbation etc.). The continuous bed is seemingly torn up and transported for short distances, as indicated by their angular outlines, either by current or subaquatic slumps. Undoubtedly, a critical slope is needed in the source area onto which these clasts rolled down. Fragments were accumulated at the toe of their parent areas by an action of one or more of the following factors: storms, floods, catastrophic waves, earthquakes etc. $[28,29,30]$. The amount of clay/carbonate matrix is considerably low and it is interpreted as an indication of separate phase of sedimentation. After the deposition of the very coarse clasts, the fine material was kept in suspension and deposited mostly beyond the zone of fragments' deposition. A quiescence episode followed the first turbulent one. During this rather calm period, which probably lasted much longer time, the fine clayey material was deposited even in the area of fragments accumulation. Some of the clay particles had infiltrated into the interstices of the conglomerates [29, $30,31]$.

2) Dolomitized Biomicrite Microfacies: This microfacies is found at many levels. The allochems are dominated by fossils with some minor content of peloids and intraclasts. The fossil content is extremely variable. At certain level in KH-6 at Ansab area (drilling depths 392-452 metres), the rocks can be assigned to as biomicrudite (or packed foraminiferal micrudite), i.e. coquina (Figure-( 7 and 8).

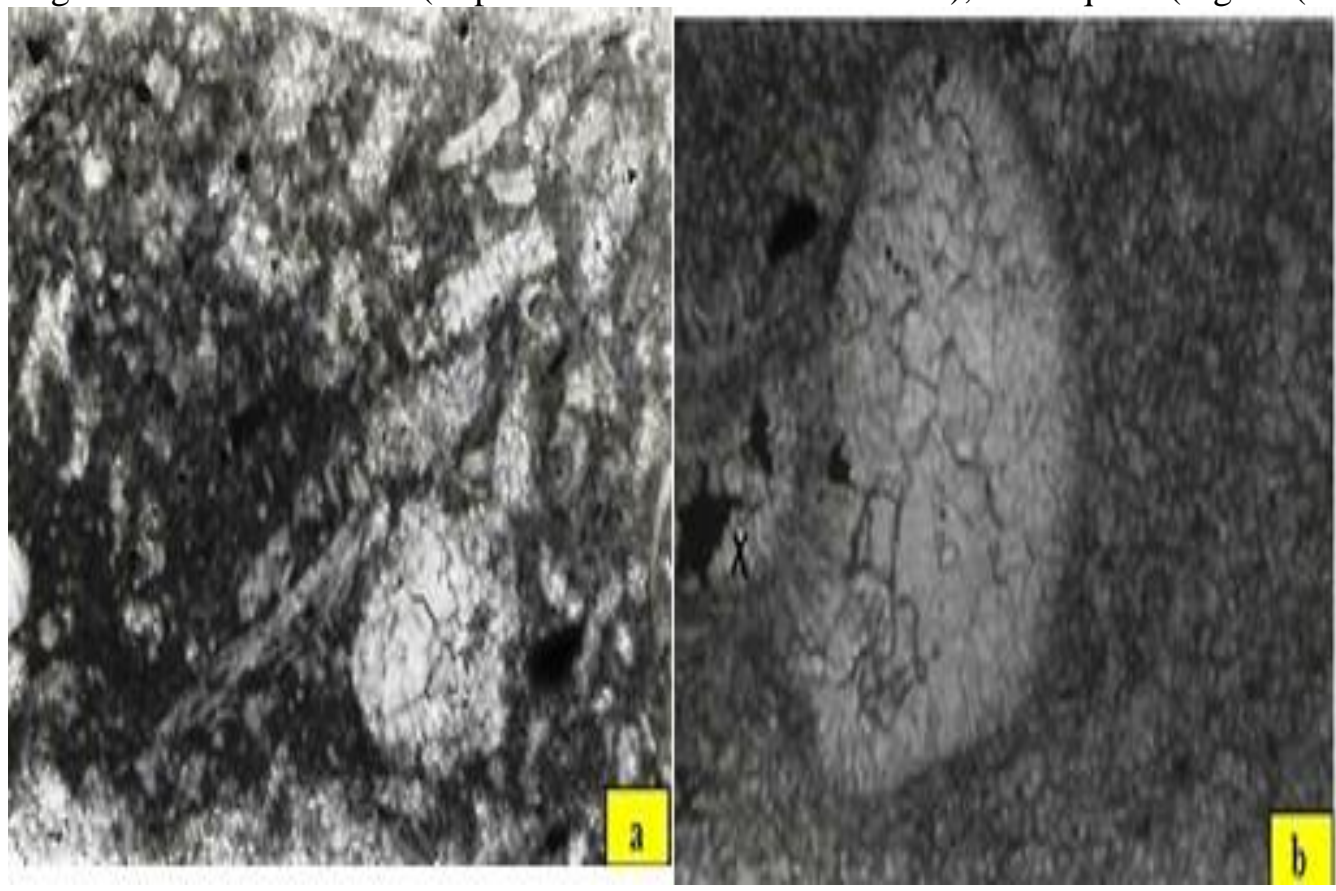

Figure 7-Photomicrograph of dolomitized biomicrite from the Tayarat Formation, borehole KH-4 at Takhadid. The groundmass is dolomite and clayey admixtures whereas the skeletal fragments are partly calcite. a) Dolomitized biomicrite (plane polarized light x35). b) Dolomitized biomicrite showing both drusy and blocky cements. The drusy cement surrounds the tests both externally and internally. The blocky cement in the small fossil (X) did not completely fill the internal gap (Planepolarized light and $\mathrm{x} 40$ ). 


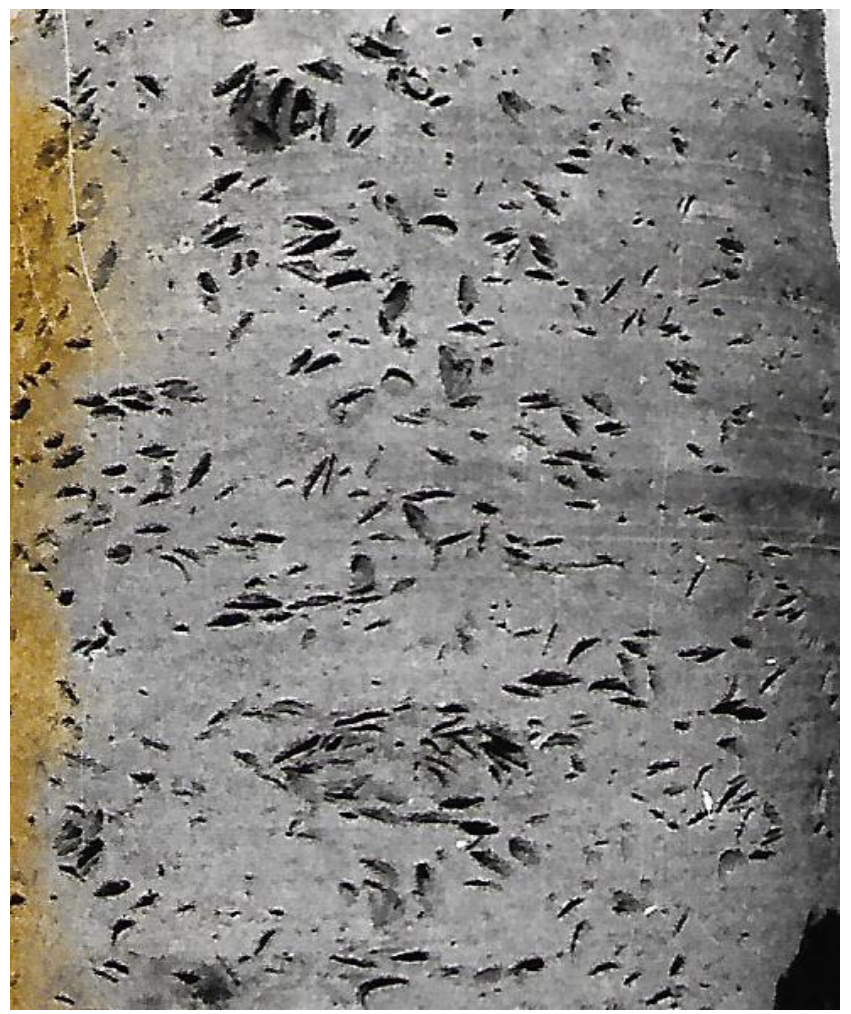

Figure 8-Packed biomicrudite from the Tayarat Formation, KH - 6 at Ansab (drilling depth $494.4 \mathrm{~m}$ ). Biomoldic porosity is high. Diameter of the core is $11 \mathrm{~cm}$.

The fossils are diversified, including foraminifers, bryozoan, coralline algae, pelecypods, and gastropods (Figure- $4 \mathrm{a}$ and $\mathrm{b}$ ). The allochems are embedded in micrite and/or clay/micrite matrix. The clay admixtures are extremely variable, hence this facies range from pure carbonate to marl. Zoned fine- to medium-crystalline dolomite rhombs and mosaic are frequent. At certain instances, the dolomitization is so intensive that the original texture is almost completely obliterated. However, "ghost" textures helped at many instances to deduce the original texture.

Rich fauna indicate normal salinity and an open circulation sea. Abundance of micrite and clay admixture reflects quieter sheltered water, where the 'fines' could settle and the organic debris were buried intact, irrespective to size or fragility. It was hence believed that there was some partial protection, possibly caused by discontinuous barrier of coral or bryozoan reef or shoal. These deposits seem to have suffered from late diagenetic processes which can be deduced from the nature of the dolomite crystals, its discursive distribution, and the high porosity of the succession.

3) Biomicrosparite Microfacies: This microfacies incorporates rocks which comprise both allochems and calcite cement. They are consanguineous with Dunham's wackestone. The allochems are represented by a variety of fauna of various sizes, such as echinoids, gastropods, pelecypods, forams, coral, algae etc., with occasional biomolds (Figures-4 and 9).

The cement is represented mostly by dolomitic microspar. The microspar is 8 to 20 microns in diameter. This microfacies represents field lithofacies named calcsiltite. Solitary and scattered zoned dolomite crystals are commonly found floating in the microsparite background. The dolomite crystals are found on some occasions clustered to form a mosaic texture. Porosity of the rocks of this microfacies is variable. Some rocks are massive, i.e. with porosity ranging from 0 to $2 \%$. The pores are generally in the form of mesovug and intraparticle. The porosity in other rocks, occurring less frequently, ranges from 2 to $10 \%$. The pores are mostly in the form of mesovug and biomolds.

The depositional environment inferred for this microfacies is believed to be the same as that of the biomicrite microfacies. Microspar is restricted to recrystallization (neomorphism) of micrite. The neomorphic enlargement of cement seems to have taken place prior to the dolomitization.

4) Mudrocks Lithofacies: It is a subordinate in the late Campanian-Maastrichtian sequence, consisting of shale, claystone and marl layers. Three sublithofacies are recognized in this lithofacies, which are described below: 
4a) Black bituminous shale sublithofacies: This sublithofacies is present near or at the top of the late Campanian-Maastrichtian sediments. In $\mathrm{KH}-3$ and $\mathrm{KH}-4$, it is located at the contact with the Paleogene Umm Er Radhuma Formation. In KH-6 and KH-7, it is found at many levels in the few metres of the late Campanian-Maastrichtian sequence, as well as in the lower few metres of the Umm Er Radhuma Formation. The contact there is gradational.

Palynological study on three specimens from KH-3, KH-4 and KH-6 showed the presence of Botryococcus braunii Kutz [32]. This indicates that the bitumen is primary because of the presence of the hydrocarbon producing algae. According to the palynomorphs assemblage, it has been deduced that the black bituminous shale was deposited in a marine/marginal lagoonal environment. A brackish water environment is not excluded but is considered less likely.

4.b) Bluish grey claystone sublithofacies: This facies is restricted to the Hartha Formation, which is partly penetrated in KH-6 at Ansab area only. It is found associated with gypsum-anhydrite nodules and nodular beds. Some gastropods and pelecypods are found in these claystones. It was most probably deposited in a quiet lagoon of high salinity.

4.c) Claystone with disseminated dolomite rhombs sublithofacies: This sublithofacies is found as thin beds throughout the late Campanian-Maastrichtian sequence at several levels. The dolomite rhombs are disseminated in a clay and micritic clay/carbonate groundmass (Figure- 9). The dolomite rhombs are fine to medium sized and generally show zonality. Few planktonic forams and echinoid fragments are found frequently. Other components, such as phosphate grains and pyrite-filling patches occur at various levels (Figure-9). Secondary gypsum and calcite crystal aggregates are also recognized.

This claystone sublithofacies with pelagic or planktonic fauna and echinoids fragments reflect a long period of calm sedimentation away from the influence of carbonate clasts. Echinoid fragments were deposited in a deeper zone due to their low density, which is caused by pores filled with air (and gas) and travelled for longer distances floating before final settling. The dolomite rhombs were probably formed by a subsequent diagenetic effect. Magnesium is probably released from the Mg-rich clay minerals.

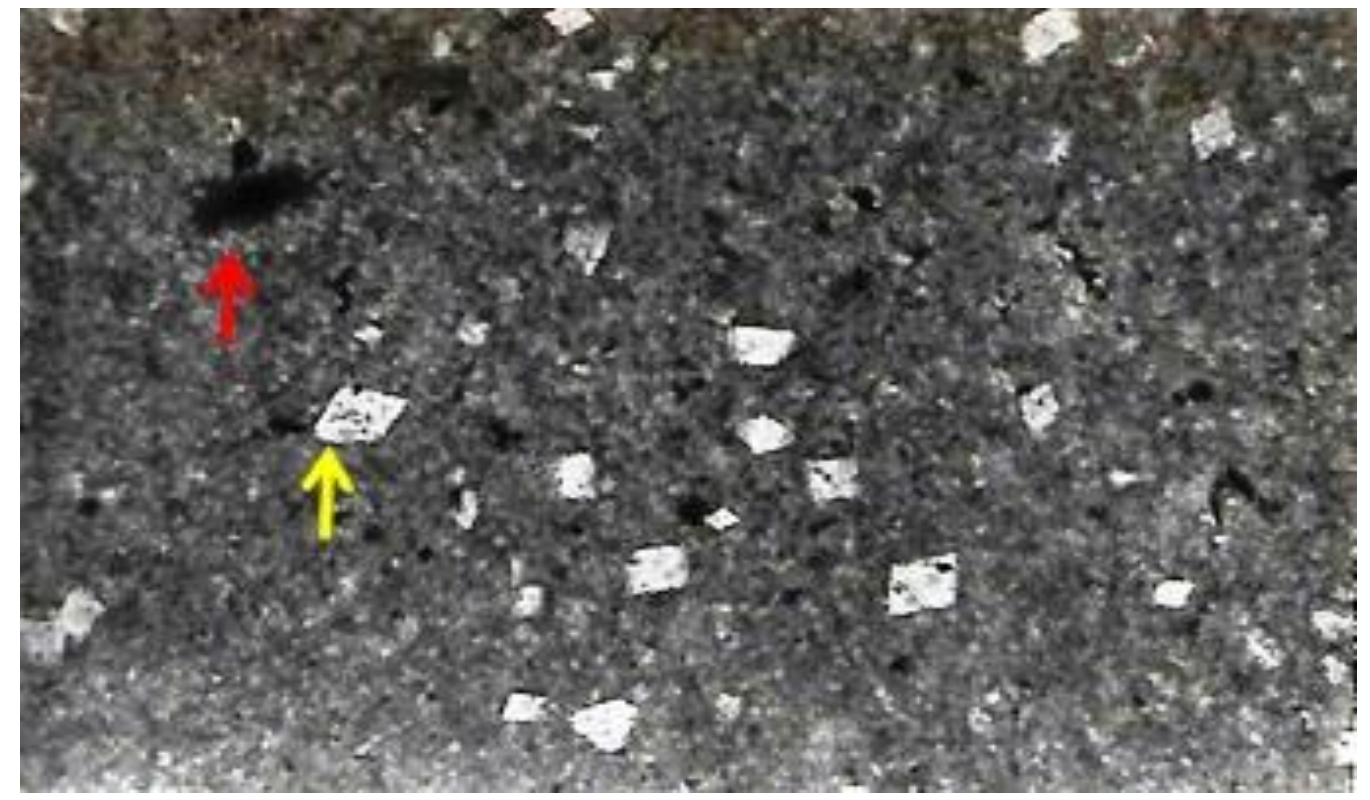

Figure 9-Claystone with disseminated dolomite rhombs (yellow arrow) from KH-4 at Takhadid. Dolomite rhombs are sparse and clear; seem "floating" in clay/carbonate aphanocrystalline matrix. Pyrite fillings (red arrow) represent plane polarized light, x35.

5) Sulphates-rock Lithofacies: The name sulphate is used here to indicate the association of gypsum and anhydrite. The sulphate-rock lithofacies is found in the form of nodular beds and nodules in the Hartha Formation and as few scattered nodules in the Tayarat Formation.

The sulphates nodules in the Tayarat Formation are solitary, sparse, and large, having up to $15 \mathrm{~cm}$ diameter (Figures-(4a and b). Generally, these nodules have a large centre of sugary white, crystalline mosaic of gypsum and anhydrite with a rather thin and fibrous rim of gypsum. Other forms of 
sulphates were also found, such as veinlets, micro-concretions, rosettes, and laths. Celestite is not uncommonly found, being associated with the gypsum and anhydrite (Figure-4c).

The thick beds of sulphates in the Hartha Formation are formed almost entirely of nodules (Figure-12). Some veinlets and rosettes of gypsum occur far less frequently. Such beds are termed here as nodular evaporites. The sedimentary structures are sometimes destroyed by hydration-dehydration processes. Nonetheless, the structures encountered include the enterolithic folding, chicken-wire texture (Figure10), and wispy, massive, and occasionally laminated evaporites. Carbonate-clay rim usually circumscribes the nodules. This rim is sometimes veneer or even absent. Clay minerals and carbonates are commonly found as inclusions in the nodules, giving rise to poikilotopic texture (Figure-5).
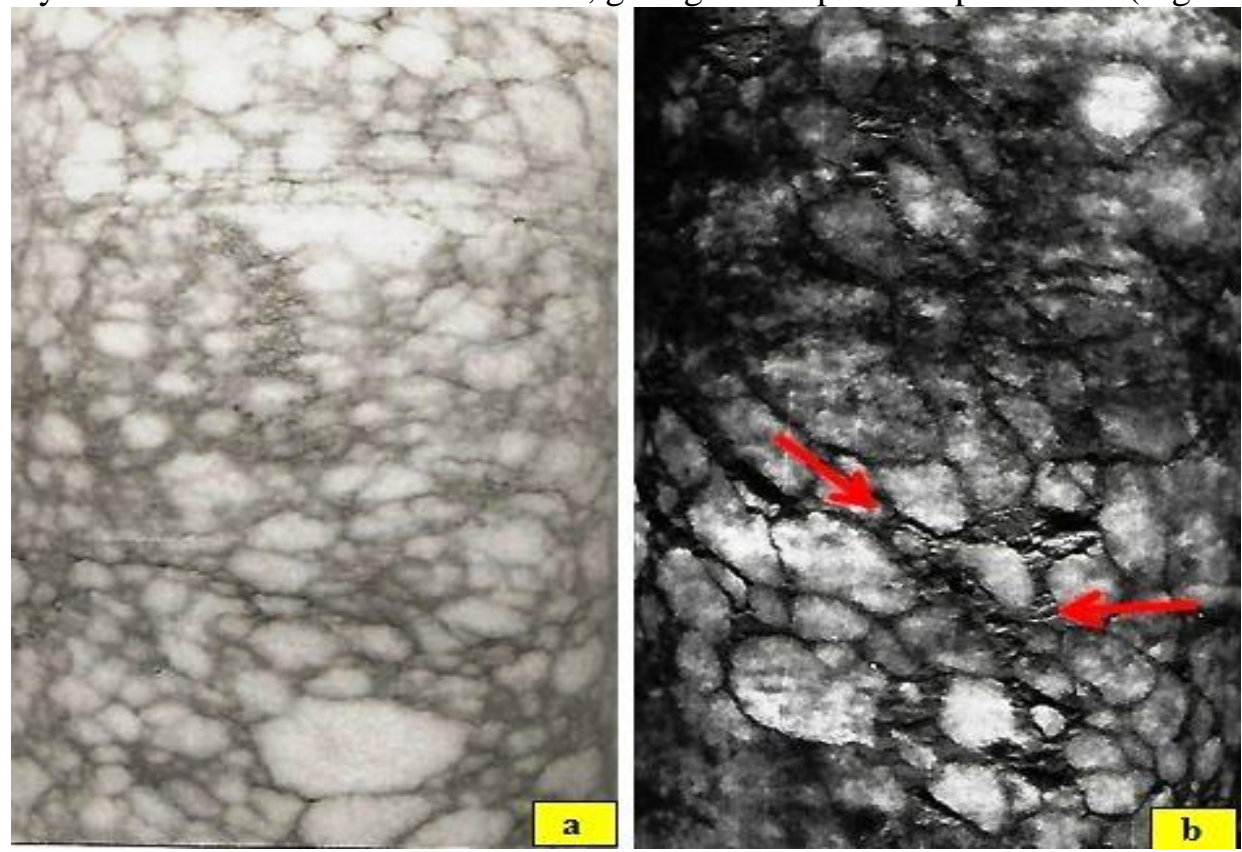

Figure 10-Nodular gypsum from: a) the Hartha Formation, KH-6 at Ansab (drilling depth 584.0 metres) showing chicken-wire texture. Gypsum nodules are circumscribed by thin filament of carbonate/clay rim (diameter of the core is $11 \mathrm{~cm}$ ). b) Gypsum nodules from the Hartha Formation, KH-6 at Ansab (drilling depth 584.0 metres) showing chicken-wire texture and the nodules which truncate the original laminations (indicated by arrows, diameter of the core is $11 \mathrm{~cm}$ ).

In the Hartha Formation, this lithofacies indicates that the deposition of evaporite occurred by diagenetic replacement of the pre-existing clay/carbonate mud. The diagenetic alterations took place at early stages of the physicochemical changes, almost penecontemporaneous to deposition. Such alteration generally takes place in continental sabkhas [33], coastal sabkhas [34], and at the rims of some lagoons, such as the Laguna Madre, Texas [35].

The association of marine fauna excludes the first possibility. It is rather difficult to choose one satisfactory model due to lack of unequivocal evidence. Nevertheless, the authors are inclined to believe that the deposition took place in a semi-barred lagoonal environment, especially because of the development of thick evaporite and lack of criteria that characterize the peritidal environments, such as stromatolites. On the other hand, the nodules in the Tayarat Formation are believed to have formed at later diagenetic processes, i.e. after changing of the depositional regime of the Tayarat deposits. The ascending and descending intrastratal solutions were rich in sulphates, as they originate from the Hartha Formation below and the Paleogene succession above.

6) Crystalline Dolomite Lithotype: This class incorporates rocks which are intensively dolomitized. The dolomitization was so severe that the original texture cannot be recognized. They were assigned the term lithotype because they are of diagenetic origin and do not represent depositional environment. This lithotype is usually formed of dolomite crystals showing inequigranular subhedral to euhedral mosaic texture. These subhedral, rarely euhedral, crystals show zoning with frequent dark nucleus (Figure-11). 

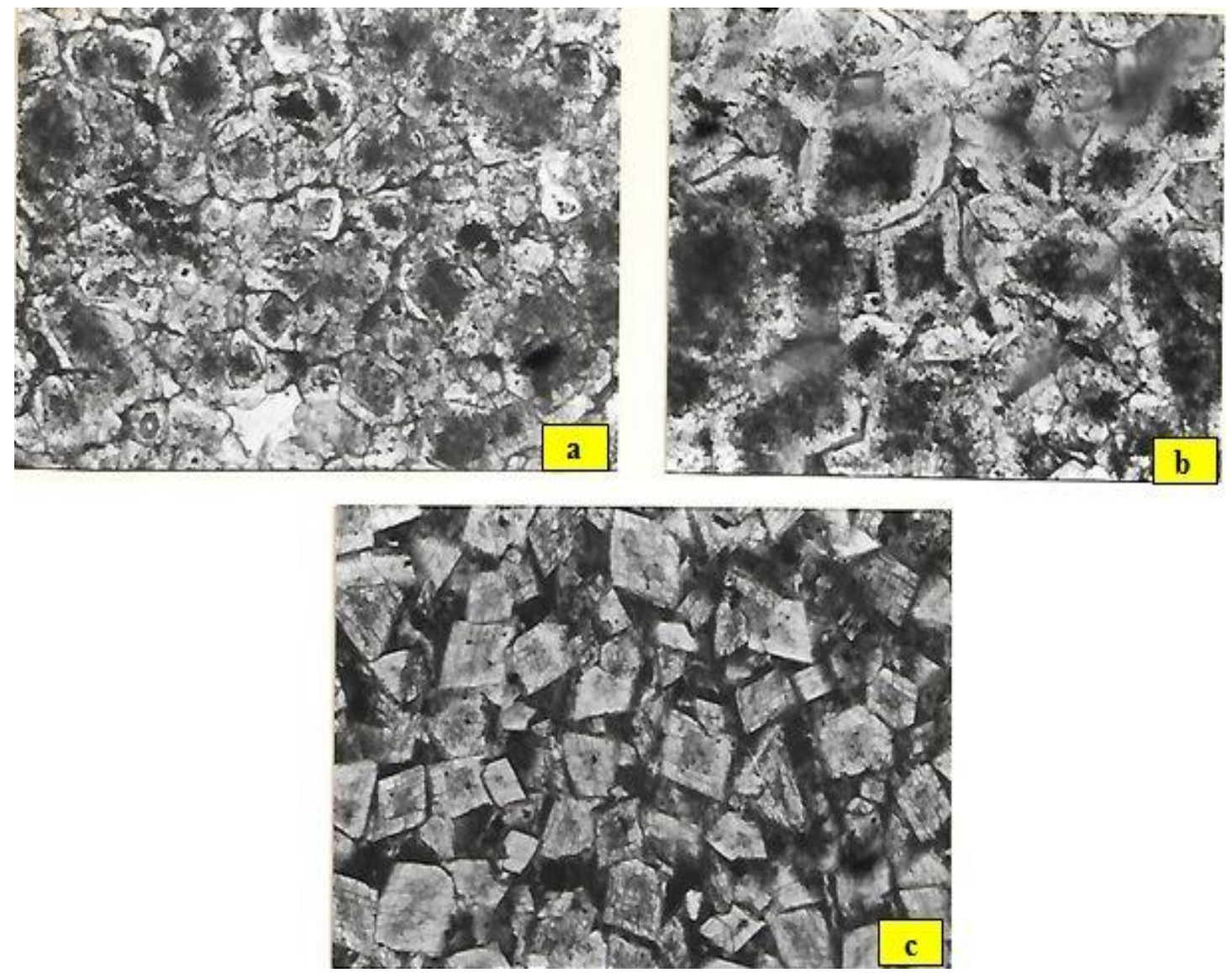

Figure 11- Photomicrographs of fine to medium crystalline dolomite from Tayarat Formation from KH-4 at Takhadid: a) Mosaic of the fine, zoned dolomite crystals with cloudy centres and successive dolomite growth (Plane polarized light $\mathrm{x} 35$ ); b) Details of a mosaic texture with organic compounds filling the intercrystalline pores (Plane polarized light x35); c) Mosaic of dolomite rhombs with organic compounds filling the intercrystalline pores. Zoning is faded and the crystal centres are rather clear. The inclusions make vague zones only (Plane polarized light x35).

Skeletal grains are occasionally noticed as "ghosts", biomolds, or partially preserved. The identified fauna are forams (orbitoides large coiled loftusia and globigerina), crinoid fragments and ossicles, corals, gastropods, pelecypods and algae. Non-skeletal grains are less frequent. Pellets and peloids are more common than intraclasts. Ooliths have not been reported in this sequence. Clay admixtures are present in the interstices at many depths. Organic matter and phosphate fragments are commonly found as scattered in this facies. Minor amounts of iron pyrites are observed as framboids and small nodules. Gypsum rosettes are found occasionally. Near the top of the formation, in KH-6 at Ansab area, vanished evaporites are noticed (drilling depth 279 metres). Porosity generally ranges 2 $10 \%$, although at few intervals it exceeds $10 \%$. The pores are mesovugs, mesobiomolds, and meso and microintercrystalline.

\section{Depositional Environments}

The sedimentation seems to be almost continuous in keyholes KH-6 and KH-4, as the Danian is most probably present whereas there is an eminent unconformity in KH-3 and KH-7. During the Maastrichtian period, the sea seems to have transgressed over the area. This is evident by the presence of planktonic fauna of the Shiranish Facies as tongues in the Tayarat Formation overlying the evaporitic Hartha Formation.

The deposition seems to have taken place in the central reef - fore reef area with some intervals, which can be attributed to back reef. The absence of any facies, which reflects isolated back-reef lagoon (i.e. hypersaline and/or super saline conditions), suggests that the reef was patchy and did not lead to the isolation of water in the middle shelf region.

The sequence in KH-6 at Ansab area shows that the Hartha Formation is evaporitic, possibly with supratidal sabkha deposits. The overlying Tayarat and Shiranish Formations reflect that the deposition 
took place in a warm tropical to subtropical reefal and open marine conditions. Some effects of deep marine conditions are evident by the presence of Shiranish facies. The deep marine facies supervene the reefal Tayarat near the top of the Maastrichtian succession. Restricted lagoons seem to have dominated the scene in the Southern Desert area during the end of the Cretaceous. These lagoons are deduced by the impartial distribution of the black bituminous shale over the whole area, which is observed in our keyholes and the other boreholes in the area [4].

\section{Conclusions}

The late Campanian-Maastrichtian sequence comprises three distinct lithostratigraphic units, namely Hartha, Shiranish, and Tayarat Formations. Numerous diagenetic changes affected the sequence, such as neomorphic replacement, dissolution, dolomitization, and sulphate development. Some are so severe that they obliterated the primary textures.

The lowermost Hartha Formation is characterized by evaporite deposition, representing coastal sabkha environment. The topmost unit is the Tayarat Formation which is characterized by limestones and dolomitic limestone representing deposition of patchy reef-fore reef environment. A tongue of the Shiranish Formation in KH-6 at Ansab area infers hemi-pelagic pelagic environment. Restricted lagoons seem to have dominated the scene towards the closure of the Cretaceous, as indicated by the black bituminous shale. The few scattered evaporite nodules in the Tayarat Formation are late diagenetic, unlike the underlying Hartha Formation.

\section{Acknowledgments}

The authors would like to thank the administration of the Iraq Geological Survey for giving access to the raw data.

\section{References}

1. Basi, M.A., 1983. The Petrographic Study of Abo Rudham Keyhole. Unpublished report, Iraq Geological Survey, Baghdad, Iraq.

2. Tamar-Agha, M.Y. 1983. Geology of the Southern Desert (Blocks 1, 2, 3). Unpublished report no 1424, Iraq Geological Survey, Baghdad, Iraq.

3. Tamar-Agha, M.Y. 1984. Final Report on Geology of the Southern Desert (Blocks 1, 2, 3). Volume 3, Unpublished report no 1446, Iraq Geological Survey, Baghdad, Iraq.

4. Bellen, R.C. van, Dunnington, H.V., Wetzel, R.Q., and Morton, D.M. 1959. Lexique Stratigraphique International, ASIE, Fascicule 10a - Iraq. Paris, 333P.

5. Al-Naqib, K. 1967. Southeastern Iraq: The Geology of the Arabian Peninsula, U.S. Geol. Surv. Prof. Paper No. 560-6.

6. Al-Siddiki, A.A.M. 1978. Subsurface Geology of southeastern Iraq. Tenth Arab Petroleum Congress, Tripoli, Libya. Paper no. 141 (B-3).

7. Al-Mubarak, M. and Amin, R.M., 1983. Report on the Geology of the Iraqi Southern Desert. Unpublished report no 1380, Iraq Geological Survey, Baghdad, Iraq.

8. Al-Ani, M.Q. and Ma'ala, K.A. 1983. Report on the regional geological mapping of South Samawa area. Unpublished report no 1348, Iraq Geological Survey, Baghdad, Iraq.

9. Al-Sharbati, F. and K. Ma'ala 1983. Report on the regional geological mapping of Southwest Busaiya area. Unpublished report no 1346, Iraq Geological Survey, Baghdad, Iraq.

10. Al-Janabi, S.A.F., 1986. Sedimentological and mineralogical studies of the Upper Cretaceous sequence in KH-6 at Ansab area in South Iraq. Unpublished M.Sc. thesis, University of Baghdad, $125 \mathrm{p}$.

11. Tamar-Agha, M.Y. and Al-Janabi, S.A.F., 2012. Palygorskite in the Tayarat Formation (Late Cretaceous), Well KH-6 at Al-Ansab, Southern Desert of Iraq. In: K.S. Al-Bassam (Ed.), The Iraqi Palygorskite, Iraq Geological Survey, pp. 11-38.

12. Tamar-Agha, M.Y. and Al-Sagri, K.E.A., 2015. Shedding Further Light on Upper Cretaceous Neogene Subsurface Lithostratigraphy of Southwestern Iraq. Iraqi Journal of Science, 56(1C): 798-827.

13. Fouad, S.F. 2014. The Tectonic Map of Iraq, (scale 1: 1000 000, 3rd edition). Iraq Geological Survey.

14. Al-Hadithi, T.M.S. and Al-Mehaidi, H.M. 1982. Final Report on PhotogeologicalHydrogeological survey, unpublished report, GEOSURV Library, Baghdad. 
15. Sharland, P.R., Archer, R., Casey, D.M., Davies, R.B., Hall, S.H., Heward, A.P., Horbury, A.D., Simmons, M.D. 2001. Arabian Plate Sequence Stratigraphy. GeoArabia, Special Publication 2, Gulf PetroLink, Manama.

16. Darmoian, S.A. 1975. Stratigraphy and micropaleontology of the Upper Cretaceous Aruma Supergroup, South Iraq. Jour. Geol. Soc. Of Iraq. Special Issue.

17. Owen, R.M.S. and Nasr, S.N. 1958. The stratigraphy of the Kuwait-Basra area. In: L.G. Weeks (Ed.). Habitat of Oil a Symposium, American Association of Petroleum Geologists, Special Publication, pp. 1252-1278.

18. Folk, R.L. 1959. Practical petrographic classification of limestones. Am. Assoc. Petroleum Geologist Bull., 43: 1-38.

19. Dunham, 1962. Classification of carbonate rocks according to depositional texture. In: W.E. Ham (Ed.), American Association of Petroleum Geologists, Mem. 1: 106-121.

20. Tucker, M.E. and Wright, V.P. 1990. Carbonate Sedimentology, Blackwell, Oxford, 482p.

21. Sibley, D.F. 1982. The origin of common dolomite: clues from the Pliocene. J. Sedim. Petrol., 52(4): 1087-1100.

22. Friedman, G.M. 1964. Early diagenesis and lithification in carbonate sediments. J. Sedim. Petrol., 35: 643-655.

23. Friedman, G.M. and Ali, S.A. 1981. Diagenesis of carbonate rocks: Cement-Porosity relationship. SEPM Reprint Series, Number 10, 295p.

24. Kaldi, J. and Gidman, J. 1982. Early diagenetic dolomite cements: Examples from the Permian Lower Magnesian Limestone of England and the Pleistocene carbonates of Bahamas. J. Sedim. Petrol., 52(4): 1073-1085.

25. Nicholas, and Seiberling, N.J. 1980. Eogenetic Dolomitization in the Pre-Tertiary of the Great Basin. In: D.H. Zenger, J.B. Dunham and Ethington (Eds.). Concepts and Models of Dolomitization. SEPM Special Publ. 28: 237-246.

26. Bathurst, R. 1975. Carbonate Sediments and Their Diagenesis. Development of Sedimentology 12, Elsevier Publishing Company, New York, 658p.

27. Mattes, B.W. and Mountjoy, E.W. 1980. Burial Dolomitization of the Upper Devonian Miette Buildup, Jasper National Park, Alberta. In: D.H. Zenger, J.B. Dunham and R.L. Ethington (Eds.). Concepts and Models of Dolomitization. SEPM Special Publ. 28: 259-297.

28. Scholle, P.A. and Ulmer-Scholle D.S. 2003. A Color Guide to the Petrography of Carbonate Rocks: Grains, textures, porosity, diagenesis. Am. Assoc. Petroleum Geologist Memoir 77, 459p.

29. Boggs Jr., S. 2011. Principles of Sedimentology and Stratigraphy, 5th ed., New Jersey, Pearson Education Inc., 670p.

30. Nichols, G. 2009. Sedimentology and Stratigraphy. $2^{\text {nd }}$. Edition, Wiley-Blackwell, Oxford, U.K., $432 p$.

31. Flügel, E. 2010. Microfacies of Carbonate Rocks: Anaysis. Interpretation and Application, $2^{\text {nd }}$ Edition, Springer-Verlag, Berlin-Heidelberg, Germany. 984p.

32. Konzalova, M. 1982. Preliminary micropaleontological (palynological) study of the Late Cretaceous-Early Paleogene sediments from the Tayarat Formation, Southern Iraq. Unpublished report, Iraq Geological Survey, Baghdad, Iraq.

33. Glennie, K.W. 1970. Desert Sedimentary Environments. Development in Sedimentology, Vol. 14. Amsterdam, Elsevier Publishing Company, Amsterdam, 222p.

34. Shearman, D.J. 1978. Evaporites of coastal sabkhas. In: W.E. Dean and B.C. Schreiber (Eds.), Marine Evaporites, SEPM short course, No.4, Oklahoma City, pp. 6-42.

35. Kerr, S.D. Jr. and Thompson, A. 1963. Origin of nodular and bedded anhydrite in Permian shelf sediments, Texas and New Mexico. Am. Assoc. Petroleum Geologists Bull., 47: 1726-1732. 